\title{
Acid-Sensing Ion Channel 2
}

National Cancer Institute

\section{Source}

National Cancer Institute. Acid-Sensing Ion Channel2. NCI Thesaurus. Code C114697.

Acid-sensing ion channel 2 ( $512 \mathrm{aa}, \sim 58 \mathrm{kDa}$ ) is encoded by the human ASIC2 gene. This protein is involved in both synaptic transmission and cation transport. 